\title{
Constitutional Review after the Arab Spring: Reforms, Challenges and Perspectives
}

\section{Francesco Biagi}

\section{Abstract}

One of the most significant trends following the Arab Spring has been the emergence and strengthening of constitutional review bodies. Jordan and Palestine established a constitutional court for the first time in their history, respectively in 2012 and 2016; the latest draft constitution of Libya provides for a constitutional court; Morocco, Tunisia, Algeria and Kuwait have reinforced the position and powers of their respective constitutional review bodies; in Egypt the Supreme Constitutional Court continues to be one of the most powerful and influential institutions in the country. The aim of this chapter is to discuss whether these new constitutional review bodies have acquired the potential to subject the executive branch to adequate checks and thus contribute to the processes of democratization more effectively compared to the past. In order to do so, I shall first briefly identify the reasons why constitutional courts and councils before the Arab Spring rarely acted as "counter-majoritarian" bodies. I shall then discuss the major novelties introduced by the recent constitutional reforms in the field of constitutional review. Finally, I shall examine some of the main challenges that constitutional courts and councils will have to face in order to fulfill their role of guardians of the constitution.

\section{Introduction ${ }^{1}$}

One of the most significant trends following the Arab Spring has been the emergence and strengthening of constitutional review bodies. Jordan and Palestine established a constitutional court for the first time in their history, respectively in 2012 and 2016; the latest draft constitution of Libya (adopted in July 2017) provides for a constitutional court; Morocco,

1 I would like to express my gratitude to Gertrude Lübbe-Wolff and Islam Mohammed for their precious comments on a previous draft of this chapter. The usual disclaimers apply. 
Tunisia, Algeria and Kuwait have reinforced the position and powers of their respective constitutional review bodies; in Egypt the Supreme Constitutional Court continues to be one of the most powerful and influential institutions in the country.

The aim of this chapter is to discuss whether these new constitutional review bodies have acquired the potential to subject the executive branch to adequate checks and thus contribute to the processes of democratization more effectively compared to the past. In order to do so, I shall first briefly identify the reasons why constitutional courts and councils before the Arab Spring rarely acted as "counter-majoritarian" bodies. I shall then discuss the major novelties introduced by the recent constitutional reforms in the field of constitutional review. Finally, I shall examine some of the main challenges that constitutional courts and councils will have to face in order to fulfill their role of guardians of the constitution.

\section{Constitutional review bodies before the Arab Spring: Weak defenders of constitutionalism}

Constitutional review was a common feature in North Africa and the Middle East (MENA region) even before the Arab Spring. In fact, after obtaining their independence, or over the following decades, a number of Arab countries established a system for reviewing the constitutionality of legislative acts. In most cases, a "centralized" model was adopted, in which constitutional review was carried out by a specialized, ad hoc constitutional court or council (as in Morocco, Mauritania, Algeria, Tunisia, Egypt, Syria, Lebanon, Kuwait, and Bahrain). Other countries, by contrast, granted the power to review the constitutionality of legislation to the Supreme Court: this was the case, for example, in Iraq, Yemen, the United Arab Emirates, and Libya. Jordan adopted a hybrid system of constitutional review: on the one hand, the Constitution vested a High Court with the power to interpret the provisions of the Constitution pursuant to a request by the Council of Ministers and the Houses of Parliament; on the other hand, according to settled case-law, ordinary courts were not entitled to apply any laws or regulations that violated the Constitution. ${ }^{2}$

2 One of the very few exceptions to this established case law was the judgment delivered by the Court of Appeal of Jerusalem in 1953 (Case 312/53). This occurred during the period (1950-1967) in which Jordan controlled the West Bank and East Jerusalem, including the Old City. In this decision the Court of Appeal held that it did not have jurisdiction to review the constitutionality of legislation ("It is not 
However, constitutional review bodies rarely guaranteed respect for constitutional principles or protection for fundamental rights and freedoms - the Egyptian Supreme Constitutional Court being (at least during certain periods) one of the very few exceptions (see Brown 1998: 89). A number of different reasons explain the inability of these institutions to act as effective defenders of constitutionalism. First of all, it must be considered that constitutional review bodies usually enjoyed limited independence vis-à-vis the executive branch. This was partly due to the fact that the head of state often dominated the system for appointing the members of constitutional courts and councils (as was the case in Egypt, Syria, Tunisia, and Morocco). In Egypt this was even more evident due to the fact that neither the 1971 Constitution nor Law 48 of 1979 on the Constitutional Court specified the number of members of the Court. Due to this lack of provision, there could be an infinite number of justices. As a result, "if a Chief Justice and President both dislike[d] the decisions of majority on the Court, they [could] collude to pack the court with justices sympathetic to their views" (Lombardi 2008: 242). This is precisely what happened in the early 2000s, when President Mubarak decided to appoint additional "loyal" members in order to shift the balance in his favor (as will be discussed in greater detail below).

The eligibility for reappointment of the members of constitutional review bodies represented another serious threat to the independence of these institutions. In Syria, for example, the four-year term could be renewed, whilst in Tunisia the three-year term was renewable twice. The shortcoming regarding the renewability of the term of office is evident: since court's members "rely on continued executive support for their tenure [they] have little incentive to exercise any measure of judicial independence" (Choudhry and Bass 2014: 30).

Another reason explaining the weakness of constitutional courts and councils concerned the nature of their decisions. Indeed, while their binding status was proclaimed (in more or less explicit terms, depending on the country) in the vast majority of pre-2011 Arab constitutions, there were still a few exceptions, such as Tunisia. For a long time, (i.e. until 1987) the country did not have any constitutional review mechanism in the form of a constitutional court or council, as it was the President of the Republic who was responsible for guaranteeing respect for the 1959 Constitution.

the Court's right to verify the constitutionality of these laws [...] as long as they are adopted by Parliament and ratified by His Majesty the King”). I am grateful to Professor Numaan Elkhatib for bringing this judgment to my attention. 
A Constitutional Council was established in 1987 by presidential decree (No. 87-1414 of December 16, 1987), and was subsequently granted a constitutional status in 1995. The Council was mainly a political body, and was in fact responsible for reviewing the constitutionality of legislation only prior to enactment (ex ante review). Moreover, for the first eleven years of its existence, the Council was only able to issue advisory opinions, which were confidential and communicated exclusively to the President of the Republic, who was the only authority entitled to refer bills to the Council (see Gallala-Arndt 2012: 252). Therefore, intervention by the Constitutional Council was much more akin to involvement within an auxiliary procedure to the decision-making process than to genuine constitutional review (see Ben Achour 2008: 18). Although following a series of reforms in 1998 and 2004 it ceased to be a purely advisory body, the Council never fully acquired full decision-making or judicial powers (see Ben Achour 2008: 23).

The procedural gateways to constitutional courts and councils represented another major weak point of these institutions. Indeed, in a number of countries constitutional standing to refer cases to constitutional review bodies was significantly limited, which had the obvious consequence of drastically reducing the overall number of legislative acts on which these institutions could rule. This "stranglehold" on access was very evident in the Maghreb countries. Indeed, with the exception of Algeria (which also contemplated ex post abstract review), constitutional councils in the Maghreb were only empowered to review the constitutionality of legislation before its promulgation (ex ante review). Moreover, only (usually very few) political authorities had standing to refer a case to the constitutional council. In Tunisia, for instance, as already mentioned above, the President of the Republic was the only authority entitled to refer bills to the Constitutional Council. Another example is Algeria, where only the President of the Republic and the Speakers of the two Houses of Parliament could apply to the Constitutional Council.

It should be noted that, even when the procedural gateways were broader, still very few cases were referred to constitutional review bodies. It is sufficient to consider the case of Morocco, where the Constitution granted the power to appeal to the Constitutional Council not only to the King, the Prime Minister and the speakers of the two Houses of Parliament, but also to the parliamentary opposition (i.e. one-quarter of the members of either House of Parliament). However, over the period $1994-2013$ the opposition only referred a matter to the Constitutional Council four times (see Benabdallah 2013: 20), despite considerable doubts as to the constitutionality of a whole series of laws. It has been argued that "the opposition's 
lack of trust in the Moroccan Constitutional Council can be explained by its perceived bias in favor of the government", since the Council "has been firm in the defense of government prerogatives" (Gallala-Arndt 2012: 254). This approach comes as no surprise, especially if one considers that the Constitutional Council was considered as the "chien de garde de l'exécutif"3 (Bendourou 2004: 37), and "the protector of royal prerogatives" (Fassi Fihri 2014: 154). There is also another important reason which explains this passive stance on the part of the opposition, a reason which concerns a more general attitude amongst Moroccan political parties. Indeed, in some cases constitutionally controversial bills were not referred to the Council, having attracted a "consensus" among the different political parties represented in Parliament. ${ }^{4}$ This confirms the "politics of consensus", which has characterized Morocco for many decades. According to this notion, the role and absolute powers of the sovereign are not a matter for discussion or difference of opinion among the parties. Regardless of their ideological orientations, political parties "seem comfortable with not taking the initiative and leaving the palace full control of the political game and orientations of the country" (Maghraoui 2013: 182).

The weakness of constitutional review bodies was also closely related to their deference towards the political authorities, and in particular towards the executive branch. A clear demonstration of this deference is apparent in the doctrine whereby "acts of sovereignty" fall outside the jurisdiction of the judiciary, a doctrine that recalls the "political question doctrine" typical of the United States. However, the notion of acts of sovereignty is quite vague. In general terms, an act of sovereignty is something that states - and in particular the holder of executive authority - do by virtue of their status as sovereign actors, encompassing measures taken both at the domestic and the international level. Thus, these acts often refer to matters of internal security, public order, and foreign policy. Clearly, the aim of acts of sovereignty is to allow the executive branch to exercise broad discretionary power (see Abouelenen 2008: 181 et seq.). Not surprisingly, in some cases constitutional courts (especially in Egypt and Kuwait) abused the doctrine of acts of sovereignty in order to avoid striking down laws that were clearly unconstitutional (see Brown 1997: 121; Brown 2002: 157-

3 As is well known, this expression was originally used by Michel Debré to describe the French Constitutional Council.

4 This occurred, for example, in relation to Law May 28, 2003 on combatting terrorism, and Law November 11, 2003 on the entry and residence of foreign nationals in the Kingdom of Morocco, emigration and illegal immigration (see Bendourou 2004: 37). 
158). Thus, for example, for a long time the Egyptian judiciary considered declarations of a state of emergency to fall outside the scope of judicial review, as they were considered to result from an act of sovereignty. It should be pointed out that, far from having disappeared, this doctrine continues to be used by constitutional review bodies in the region, especially in the most politically sensitive cases. In 2018, for example, the Egyptian Supreme Constitutional Court relied on this doctrine in order to legitimize the controversial decision of the executive to cede sovereignty over the Tiran and Sanafir islands to Saudi Arabia (see Kebaish 2019: 835 et seq.). ${ }^{5}$

Finally, it is essential to take into account the context within which constitutional review bodies exercised their powers before the Arab Spring. As has been pointed out by Mauro Cappelletti, "no dictatorial or oppressive regime has ever accepted an effective, and not merely nominal, system of constitutional justice" (Cappelletti 1994: 69). North African and Middle Eastern countries - which were characterized by non-democratic regimes largely confirm this rule. There is only one significant exception, which is the Supreme Constitutional Court of Egypt. During the first phase of its existence (1980-1985), the Court focused on the safeguarding of economic and property rights, thus fulfilling the expectations of Presidents Sadat (initially) and Mubarak (subsequently). However, by the mid-eighties, the Court also started to protect civil and political rights. As a result, the Court directly clashed with the executive, which was opposed to political liberalization. Moreover, from the early 1990s under the presidency of Chief Justice Awad Mohammed El-Morr, adopting an expansive reading of the 1971 Constitution, the Court began to rely on international human rights treaties and conventions in order to guarantee even more effective protection for fundamental rights and freedoms (see Boyle and Omar Sherif 1996; Cotran and Omar Sherif 1997: 1-76; Bernard-Maugiron 1999: 17 et seq.; Bernard-Maugiron 2003: 161 et seq.). Interestingly, the Court often also promoted a liberal and modern interpretation of the principles of sharia, always with the aim of safeguarding human rights, as will be discussed in greater detail below. As a result, from 1985 until the late 1990s (a period known as "the golden age" of the Constitutional Court), despite the limits discussed above (such as a strong executive control over the appointment of the Court's members, or the (ab)use by the Court of the doctrine of acts of sovereignty), the Supreme Constitutional Court, which had initially been conceived of as an ally of the Government, turned 
into a body that (at least on occasion) constrained the executive branch. Nonetheless, "there were important limits to [the Court's] activism. At odds with its strong record of rights activism, the [Court] ruled Egypt's emergency state security courts constitutional. It also delayed issuing a ruling on the constitutionality of civilian transfers to military courts" (Moustafa 2008: 95). During the early 2000s President Mubarak put an end to the Court's boldness by packing it with regime-friendly judges. Emblematic of this was his appointment of Fathi Nagib as the new Chief Justice, the person "who had drafted the vast majority of the government's illiberal legislation over the previous decade" (Moustafa 2008: 103). In this way, the regime managed to transform the Court back into a less activist and less liberal institution (see Moustafa 2007: 178-219; Lombardi 2008: 242 et seq.).

\section{Constitutional review in post-2011 Arab constitutions: Reforms, models and external influences}

The new constitutions or constitutional reforms adopted following the Arab uprisings introduced a number of major innovations in the field of constitutional review. As mentioned above, some countries established a constitutional court for the first time in their history (Jordan in 2012 and Palestine in 2016); 6 meanwhile in Libya, although the constitution-making process is still ongoing, the last draft Constitution from 2017 provides for a constitutional court. Other countries (e.g. Morocco, Tunisia, Algeria, and Kuwait) have reinforced the position and the prerogatives of their constitutional review bodies, and in Egypt the Supreme Constitutional Court remains an extremely powerful and influential institution (see Frosini and Biagi 2015: 139 et seq.; Grote 2016: 677 et seq.).

There are various different reasons why these new constitutional review bodies have become such a fundamental element of the new constitutional frameworks. On the one hand, the establishment or reinforcement of these institutions represented a way of addressing demands made by protesters during the 2010-2011 demonstrations - protesters who were calling, inter alia, for the creation of a state based on the rule of law and a more effective protection of rights and freedoms. On the other hand, the willingness

6 It should be clarified that in Palestine the Constitutional Court had already been provided for under the Basic Law of 2003, and that the Law on the functioning of the Court had been adopted in 2006 (and was subsequently amended in 2017). 
to adopt constitutions that are more closely aligned with international standards (even if only at a formal level) became forcefully apparent, and constitutional review - as is well known - has long been considered as an essential element of a democratic country. In other cases, the establishment of a constitutional court appeared to be linked to political dynamics, including in particular to the need to provide a "constitutional veneer" for the decisions made by the President within a context characterized by a weak separation of powers.

In the following section, I shall examine some of the most significant changes introduced by the recent constitutional reforms, including:

1) the limited strengthening of the independence of constitutional review bodies,

2) the vesting of these institutions with judicial status,

3) the broadening of access, as well as

4) the expansion of their jurisdiction.

\subsection{A limited strengthening of the independence of constitutional review bodies}

In the wake of the Arab Spring, some countries reinforced the independence of constitutional courts and councils, for example by limiting the excessive influence of the executive branch in the appointment process. This is undoubtedly the case in Tunisia, where the 2014 Constitution involves all three branches of government on an equal footing in the selection of the members of the Constitutional Court: four are appointed by the President of the Republic, four by the Assembly of the Representatives of the People, and four by the Supreme Judicial Council. The independence of the Court is also enhanced by the fact that its members elect its President and Vice-President from amongst its members.

Algeria is another interesting case. First of all, the 2016 Reform of the 1996 Constitution increased the number of the members of the Constitutional Council from nine to twelve. The President of the Republic appoints one-third (four) of the members of the Council, including the President and the Vice-President of the Council; a further one-third are elected by Parliament (two judges by the People's National Assembly and two by the Council of the Nation), whilst the remaining one-third are appointed by the judiciary (two members by the Supreme Court and two by the Council of State). All three branches of government thus continue to be involved in the selection process although, in contrast to what hap- 
pened in the past, the proportion of members appointed by the judiciary has increased.

Generally speaking, the involvement of a wide range of actors in the appointments process is extremely important not only because it is likely to strengthen the independence of the constitutional court (especially in countries where the head of state is the dominus of the political and institutional system), but also because it "fosters a broad sense of political investment in the court, so that all actors have an incentive to continue supporting the court even when they are on the losing side of its decisions" (Choudhry and Bass 2014: 9).

Other changes have also contributed to the protection of the new constitutional review bodies from political influence. First of all, the countries that still do not provide for a fixed term in office are now clearly in a minority. This is the case, for example, in Syria where the 2012 Constitution continues to provide that the four-year term of the members of the Supreme Constitutional Court can be renewed. Furthermore, a number of countries have enhanced the qualifications that members of constitutional review bodies must hold, such as the level of education and professional achievement which they must have obtained, the minimum or maximum age at the time of appointment, or the list of professions or offices that are incompatible with appointment to constitutional review bodies (usually political positions) (see Choudhry and Bass 2014: 89 et seq.).

However, in several Arab countries the head of state continues to dominate the appointment system. In Syria, for example, the 2012 Constitution still grants the President the power to select all justices on the Supreme Constitutional Court. Similarly, the 1952 Jordanian Constitution (as amended in 2011) states that all the members of the Constitutional Court are appointed by the monarch. In Morocco, the 2011 Constitution continues to vest the King with the power to select half of the members of the Constitutional Court, including the President (while the other half is selected by Parliament). It should be noted that both in Morocco and Jordan (in the latter case following the 2016 Constitutional Amendment) the appointment of the members of their respective constitutional courts by the king does not need to be countersigned by the Government, thus leaving full discretion to the monarch.

Also in Egypt, the President of the Republic continues to be the key figure in the selection process, especially following the adoption of the 2019 Amendments to the Constitution promulgated in 2014. In particular, following this reform the Chief Justice of the Supreme Constitutional Court is no longer selected by the General Assembly of the Court (and then confirmed by the President of the Republic), but is directly appointed 
by the President of the Republic, choosing among the five most senior Deputy Chief Justices (i.e. the associate justices) of the Court. The role performed by the Chief Justice is of the utmost importance, since he "controls the [Court]'s docket and oversees the process of writing the Court's decisions" (see Choudhry and Bass 2014: 59). The President of the Republic also appoints the Deputy Chief Justices of the Court, choosing between two nominees: one nominated by the General Assembly of the Court, and one nominated by the Chief Justice.

A very important novelty was introduced by the 2012 Constitution, which stated that the Supreme Constitutional Court was to be composed of the President and ten justices, thus remedying the failure by the previous 1971 Constitution to stipulate the number of justices. However, this change proved to be short-lived, as the 2014 Constitution no longer specifies the number of justices on the Court: it only states that the Court must be composed of a President and a "sufficient" number of justices (art. 193). In a similar vein, even the 2012 Syrian Constitution stipulates that the Supreme Constitutional Court "consists of at least seven members" (art. 141) (emphasis added). In order to avoid the risks inherent to courtpacking schemes mentioned above, a fixed number of justices would have been preferable.

\subsection{The shift towards a "judicialization" of constitutional review bodies}

Before the Arab Spring, the strong influence of the French model of constitutional review was largely responsible for the mainly political character of constitutional review bodies in the Maghreb countries (and indeed beyond, such as in Lebanon). This political nature was apparent in a series of elements:

a) the name itself: "councils" instead of "courts" clearly indicated the non-judicial status of these bodies;

b) the appointment and composition: members of constitutional councils were mainly appointed by political actors (and in particular by the head of state), and were not usually required to have any legal background in order to be selected;

c) the type of constitutional review: with the sole exception of Algeria (which also provided for ex post review), the Maghreb countries only provided for ex ante review, as constitutional scrutiny was only allowed during (and not after) the legislative process, i.e. prior to the enactment of the law; 
d) constitutional standing: only political authorities (such as the head of state, the prime minister, the speakers of the houses of parliament, and in some cases also the parliamentary opposition) were entitled to apply to constitutional councils (abstract review); ordinary courts, on the other hand, were not granted the power to challenge the constitutionality of legislative acts (concrete review).

Many post-2011 constitutions in the Maghreb have completely overturned this political model, moving towards the "judicialization" of constitutional review, in the form of Kelsenian-style constitutional courts. First, constitutional councils have in some cases changed their name and are now called constitutional "courts" (as in Morocco and Tunisia). In Algeria, the Constitutional Council has maintained its name, although more in form than in practice. ${ }^{7}$ Second, in some countries (such as Tunisia and Algeria, as discussed above) all three branches of government - including the judiciary - are now involved in the process of appointing the members of the constitutional review bodies. Thus, political actors are no longer the only institutions empowered to select their members. ${ }^{8}$ Third, in most cases a legal background has become an essential requirement for appointment to the bench (as in Morocco, ${ }^{9}$ Tunisia, ${ }^{10}$ and Algeria ${ }^{11}$ ). Fourth, in addition to $e x$ ante review (which continues to be a distinguishing feature of these bodies), constitutional review bodies have now been vested with the task of reviewing the constitutionality of legislation also after its promulgation

7 It should be noted that the draft constitutional reform adopted in May 2020 provides for a constitutional "court" (see Biagi 2021, in this volume).

8 In Morocco, by contrast, half of the members of the Constitutional Court are appointed by the king, and half by Parliament, without any involvement of the judiciary.

9 The 2011 Constitution stipulates that the members of the Constitutional Court are chosen from among those persons with an advanced qualification in law and with judicial, doctrinal or administrative expertise who have exercised their profession for more than fifteen years, and are recognized for their impartiality and probity (art. 130(5)).

10 The 2014 Constitution provides that three-quarters of the members of the Constitutional Court are "legal experts with at least 20 years of experience" (art. 118(1)), and that the President and the Vice-President must be "specialists in law" (art. 118 (4)).

11 The 1996 Constitution (as amended in 2016) states that the members of the Constitutional Council must have experience of at least 15 years in the field of higher legal education, as a judge, as a barrister with rights of audience before the Supreme Court or the Council or State or in a senior position in the state apparatus (art. 184(2)). 
(ex post review). In particular (as will be discussed in the next section), authority to challenge the constitutionality of legislative acts has also been vested in ordinary courts (concrete review), as is the case for example in Morocco, Tunisia, and Algeria. Fifth, the reinforcement of the judicial character of constitutional courts and councils is also evident if one considers that the binding status of the decisions of these bodies has been further consolidated. In Tunisia, for example, whilst (as discussed above) under the previous constitutional framework the Constitutional Council never fully lost its mainly advisory nature, the new 2014 Constitution specifically stipulates that the Constitutional Court "is an independent judicial body" (art. 118), and that its decisions are "binding on all authorities and published in the Official Gazette" (art. 121).

It is important to stress that the "judicialization" of constitutional review bodies has not been characteristic only of Maghreb countries, but has been a common feature throughout most post-2011 Arab countries. In Egypt, for example, both the 2012 and 2014 Constitutions maintained the judicial status of the Supreme Constitutional Court. In addition, recently established constitutional courts, namely the constitutional courts of Jordan and Palestine, are clearly judicial bodies. This trend represents a significant innovation, which is likely to contribute to a more effective protection of rights and freedoms.

\subsection{The broadening of access}

Calls within the literature (see Bendourou 2004: 37; Mallat 2007, 196; Gallala-Arndt 2012: 258), and in some cases by the presidents of constitutional review bodies themselves (such as in Algeria: see Belaiz 2013: 52) to broaden access to constitutional courts and councils have been accepted by constitutional framers in most Arab countries. In the first place, they have decided to increase the number of governmental bodies with standing to apply to the constitutional courts and councils (abstract review). In Algeria, for example, only the President of the Republic and the Speakers of the two Houses of Parliament had standing to apply to the Constitutional Council, while the 2016 Constitutional Reform vested this power also in the Prime Minister and the parliamentary opposition (i.e. fifty members of the People's National Assembly and thirty members of the Council of the Nation). In Tunisia, the broadening of access to the Constitutional Court has been even more evident. In fact, the President of the Republic is no longer the only political authority entitled to apply to the Court, as the 
2014 Constitution has granted constitutional standing also to the Head of Government and thirty members of the Assembly of the Representatives.

However, a system of constitutional review can hardly be successful if only political actors - albeit increased in number - are entitled to apply to constitutional courts and councils. Therefore, the decision by most Arab framers to include (alongside abstract constitutional review) also concrete constitutional review has undoubtedly represented a major step forward. Under this system, when an ordinary judge concludes (either following a request by one of the parties or ex officio, depending on the country) that the law to be applied to the specific case violates the constitution, he/she must stay the proceedings and refer a question of constitutionality to the constitutional court, either directly or through the highest courts (as will be discussed below). The system of concrete review is likely to increase the chances of these bodies ruling on the constitutionality of legislative acts that violate fundamental rights and freedoms.

In the past, this procedural gateway was extremely rare in the Arab world, and could only be found in very few countries, including Kuwait and (in particular) Egypt, where it has been very successful: "citizens have been able to bring an enormous number of constitutional claims, both minor and momentous, to the attention of the [Egyptian Supreme Constitutional Court]. As a practical matter, then, courts have [...] permitted citizens ample access to the [Supreme Constitutional Court]" (Lombardi 2008: 240).

A distinction must however be drawn between countries that have adopted a "single-filter" system and countries that have adopted a "doublefilter" system. Indeed, some states - including Egypt, Kuwait, Palestine, and Tunisia ${ }^{12}$ - have followed the system that can be found, for example, in Italy, Germany and Spain, where all courts - including lower courts can directly refer questions of constitutionality to the constitutional court (single-filter system). Other countries - including Jordan and Algeria on the contrary, have followed the French model - introduced by the 2008 Constitutional Reform (question prioritaire de constitutionnalité) (see Fabbrini 2008: 1297 et seq.; Pouvoirs 2011) - whereby lower courts must refer the question of constitutionality to the apex courts (e.g. the Court of Cassation and the Council of State), which then decide whether or not to refer the question to the Constitutional Court (double-filter system).

12 It should be noted that the case of Tunisia is highly singular, as will be shown below. 
Comparative examples show that the double-filter system can be rather problematic, especially at the outset, as it can foster tensions between the highest courts and the constitutional court, and can hinder access to constitutional justice. For example, between 1951 and 1956 Germany adopted an access route that had some similarities with the double-filter system. Specifically, courts could only refer a question of constitutionality to the Bundesverfassungsgericht via the supreme courts. These courts did not have the power to block the referral, but had the right to submit to the Constitutional Court their own opinion concerning the question referred by the lower courts. However, within the practice of the Bundesgerichtshof (the supreme court in civil and criminal matters),

"such opinions began to take the form of all but complete judgments on constitutionality and were published in the official collection of the Bundesgerichtshof's decisions, sometimes before the Constitutional Court had rendered its decision. In 1955, the Constitutional Court declared that the supreme courts were not allowed to submit their opinions. In response, all five supreme court presidents addressed a note of protest to the President of the Constitutional Court. Finally, in July 1956, the Federal Constitutional Court Act was amended and the participation of supreme courts in the procedure of judicial referrals was abolished" (Garlicki 2007: 51).

Also in France the introduction of the double-filter system was not without its difficulties. Indeed, during the first years of operation of the question prioritaire de constitutionnalité, the Court of Cassation (although not the Council of State, see Stefanini 2013: 1 et seq.) displayed a certain level of resistance when referring cases to the Constitutional Council. The reasons for this initial reluctance on the part of the Court of Cassation include its low willingness to perform this new role, and its hesitancy in altering the judicial equilibrium (see Molfessis 2011: 89 et seq.; de Montalivet 2018: 927).

Similar problems have also arisen (or may arise) in the Arab countries that have adopted this model. In Jordan, for example, eight years after the establishment of the Constitutional Court, the extremely low number of judgments issued by this body would appear to be related - amongst other things - specifically to a certain degree of reluctance on the part of the Court of Cassation to refer questions of constitutionality to the Constitutional Court. For this reason, some justices have recommended switching to a single-filter system (Max Planck Foundation 2016-2017: 19). In Algeria, as discussed in greater detail earlier in this volume (see Biagi 2021), the double-filter system was introduced by the 2016 Constitutional Reform, and is regulated by Organic Law 18-16 on the "exception of uncon- 
stitutionality" (exception d'inconstitutionnalité), which entered into force on March 7, 2019.

The risks resulting from the adoption of a double-filter system had previously been emphasized by the Venice Commission, the advisory body on constitutional issues of the Council of Europe (Venice Commission 2011: 18). Indeed, in a document published in 2011 concerning the procedural gateways to constitutional review bodies, the Commission had stressed that "from the viewpoint of human rights protection it is more expedient and efficient to give courts of all levels access to the Constitutional Court" (emphasis added). In Morocco, the adoption of a single-filter system had been recommended by the National Human Rights Council, which had pointed out that the double-filter system "is cumbersome and may create intermediate steps between individuals and constitutional justice. Also, the time of the procedure may impact pending cases and make it difficult for individuals to access to constitutional justice" (National Human Rights Council 2013: 5). Parliament, nevertheless, did not follow this recommendation and in February 2018 adopted Organic Law 86-15 introducing a double-filter mechanism. However, this Organic Law has not yet been promulgated, having been ruled partially unconstitutional by the Constitutional Court in the Decision 70-18 of March 6, 2018 (see Chentouf 2019).

When assessing the effectiveness of concrete constitutional review, it is also particularly important to consider whether ordinary judges can refer a question of constitutionality only following a request by one of the parties to the case, or also ex officio. Whilst some countries have vested judges with the power to refer a question ex officio (e.g. Egypt, Kuwait and Palestine), other countries (e.g. Jordan, Algeria and Tunisia) have preferred not to grant such a prerogative to the courts, which can only refer a question following a request by one of the parties to the case. As regards specifically Tunisia, it should be stressed that this exclusion has been maintained in spite of the fact that, in its opinion on the draft Organic Law on the Constitutional Court, the Venice Commission recommended that the ordinary courts be granted the power to refer questions of constitutionality ex officio (see Venice Commission 2015: 8). ${ }^{13}$ Furthermore, Article 56 of the Organic Law on the Constitutional Court (2015-50 of December 3, 2015) seems to suggest that ordinary judges are not allowed to assess the merits of the

13 By contrast, in other cases the framers decided to follow the recommendations of the Venice Commission, as for example when increasing the number of the authorities entitled to apply to the Constitutional Court for ex ante review (Venice Commission 2013: 30). 
request by one of the parties to refer a question of constitutionality to the Constitutional Court. ${ }^{14}$ In other words, it would appear that the referral is automatic, and that the ordinary courts are unable to ascertain the seriousness of the issue (see Belguith 2015; Democracy Reporting International 2016 , 14). However, this uncertainty will only be clarified within the case law of the ordinary courts and the Constitutional Court once the latter has been established.

As regards access to constitutional justice, consideration must also be given to Kuwait and Palestine, which have recently taken a further step. In these two countries individuals have been granted the right to petition the constitutional court directly, in a way that partially recalls the individual constitutional complaints that can be found, for example, in Spain (recurso de amparo) and Germany (Verfassungsbeschwerde). In Palestine, Law on the Constitutional Court 3 of 2006, as amended by Law 19 of 2017, provides that the Constitutional Court must review the constitutionality of a legislative act on the basis of an "original direct lawsuit [...] raised by the aggrieved person" (art. 27(1)). In Kuwait, Law 109 of 2014 has granted to any natural or legal person the power to petition the Constitutional Court directly. In order to file an individual complaint against a legislative act, the complainant must have serious reasons to suspect that a provision of the Constitution may have been violated, as well as a direct personal interest. The Law also stipulates that, when submitting the complaint, the person must deposit 5,000 Kuwaiti dinars (around 16,500 USD) as a guarantee (see Aljidie 2018: 186 et seq.). This large amount of money risks excessively impeding access to the Constitutional Court - especially for women, who are usually financially dependent on their husbands.

It should be noted that one of the major differences between the individual constitutional complaint mechanisms introduced in Palestine and Kuwait and the ones existing in Spain and Germany refers to the object of the constitutional courts' review. Indeed, both in Palestine and Kuwait individuals are only entitled to file an individual complaint against a legislative act. On the contrary, in Spain and Germany (and in other European countries), individual complaints usually refer to "fundamental rights infringements committed by the regular judiciary or caused by the administration [...]. It is less common for complainants to (be able to)

14 Article 56 stipulates that "when an exception of unconstitutionality is raised before the courts, the latter must immediately transmit it to the Constitutional Court" (emphasis added). 
assert that the legislature has violated their fundamental rights by passing a particular piece of legislation" (de Visser 2015: 143).

\subsection{The expansion of jurisdiction}

It is well known that the core function of constitutional courts and councils is to review the constitutionality of legislation. Over the last few decades, however, these bodies have also been granted a number of functions over and above the constitutional review of legislation stricto sensu, namely the "ancillary functions" (Ginsburg and Elkins 2008: 1431 et seq.). This has also occurred in the Arab world, where constitutional review bodies - even before the 2011 uprisings - were vested with the task, for example, of reviewing the validity of the elections (e.g. in all the Maghreb countries, Lebanon and Kuwait), verifying the incapacity of the president of the republic (e.g. in Algeria) or the vacancy of that office (e.g. in Algeria and Tunisia), deciding on the impeachment of the president of the republic (e.g. in Syria), resolving conflicts between state authorities (e.g. in Egypt), adjudicating on disputes between the central government and sub-state entities (e.g. in the United Arab Emirates and Iraq), or reviewing the constitutionality of international treaties (e.g. in Algeria and Tunisia).

The constitutional reforms adopted in the wake of the Arab Spring have in numerous cases further expanded the jurisdiction of constitutional courts and councils. The Tunisian Constitutional Court is emblematic of this trend. Among its numerous competences, the Court is responsible, for example, for resolving disputes between the President of the Republic and the Head of Government. In the light of the establishment of a semi-presidential regime in the 2014 Constitution (under which executive power is genuinely split between the President and the Head of Government, see Biagi 2018: 413 et seq.), the Court's power to resolve these disputes will be of the utmost importance. This task, however, will be far from easy. One need only consider the tensions between former President Béji Caid Essebsi and Head of Government Youssef Chahed (see Mekki 2018), or the risk of dealing with situations involving cohabitation, i.e. when the President belongs, for instance, to a secular party whereas the Head of Government belongs to an Islamist party, or vice versa.

Another extremely important function of the Tunisian Constitutional Court consists in the power to review presidential declarations of a state of exception. The influence of the 2008 French Constitutional Reform is particularly apparent since (the new) Article 16 of the French Constitution 
makes provision for a state of exception in a manner extremely similar to Article 80 of the Constitution of Tunisia. Specifically, thirty days after the entry into force of the emergency measures, and at any time thereafter, the President of the Assembly of the Representatives of the People or thirty of its members may apply to the Constitutional Court with a view to establishing whether or not the circumstances are still exceptional. This prerogative of the Constitutional Court seems to be particularly significant as it helps to prevent the President from abusing the power to declare a state of emergency.

It should also be noted that the Tunisian Constitutional Court is now one of the constitutional review bodies that has the power to review the constitutionality of constitutional amendments not only on procedural grounds, but also on substantive grounds (as is the case also in Algeria (see Biagi 2017: 3 and 12)). The other ancillary functions of the Tunisian Constitutional Court include the power to review the constitutionality of international treaties before the draft law approving them is signed, the power to rule that the office of the President of the Republic is temporarily or permanently vacant, as well as the power to decide on the impeachment of the President of the Republic.

It should come as no surprise that a high number of ancillary functions have been vested in constitutional review bodies. These are, generally speaking, highly reputed bodies, and often "institution[s] with a reputation for success [are] given further tasks" (Ginsburg and Elkins 2008: 1454). However, assigning ancillary functions to constitutional courts and councils comes with its advantages and drawbacks. On the one hand, one of the major advantages - as pointed out by Tom Ginsburg and Zachary Elkins - is that these bodies represent

"political insurance in the face of uncertainty. Constitutional designers know there will be political conflict down the road, but they cannot anticipate who will be on what side of the issues and may anticipate that they are not in the majority. This will, ceteris paribus, lead them to empower a downstream actor who can fill gaps in the constitution and resolve disputes so as to maintain the system" (Ginsburg and Elkins 2009: 1454).

On the other hand, however, ancillary functions also entail disadvantages. First of all, vesting a very high number of powers in constitutional courts risks overloading these institutions, thus hindering the effectiveness of their action. Moreover, granting them the power to resolve issues of extreme political sensitivity risks undermining their image as neutral and independent bodies. 
The ancillary functions discussed above can be found in a number of different countries all around the world - and not only in the MENA region. A peculiar function that may be vested specifically within courts in Islamic countries is the power to interpret sharia, as is the case, for example, in Egypt. Between 1980 and 2011, the Supreme Constitutional Court took the view, in the light of Article 2 of the 1971 Constitution (which stipulated that "Principles of sharia are the main source of legislation"), that Parliament was required to abide by sharia principles when drafting laws, and that any legislation at odds with these principles would have to be declared unconstitutional. ${ }^{15}$ The Court also clarified that legislation could only be struck down on the basis of "absolute", "definitive" principles of sharia (i.e. principles that are absolutely certain with respect to their authenticity and meaning), but not also of "relative" principles (i.e. principles the authenticity and meaning of which are not certain). Moreover, legislation had to be consistent with the "goals" of sharia. ${ }^{16}$ It is crucial to point out that, when interpreting sharia principles, the Court in several cases "reflected liberal modernist sensibilities" (Brown \& Lombardi 2016, 254), thus promoting liberal values and the protection of human rights, including women's rights (see Constitutional Jurisprudence on Fundamental Rights 1996, 229 et seq.; Lombardi 2008, 246-249). The Salafists, which were strongly opposed to this understanding of Islam, were able to impose their view during the 2012 Constitution-making process, confirming the power of the Supreme Constitutional Court to review the compatibility of laws with sharia principles, but limiting the possibility to interpret these principles in a modernist fashion. Indeed, the 2012 Constitution retained the same wording as Article 2, whilst also including a new provision laying down a specific definition of sharia principles, namely Article 219, which stipulated that "The principles of sharia include general evidence, foundational rules, rules of jurisprudence, and credible sources accepted in Sunni doctrines and by the larger community". The aim of this Article was to force the Court to depart from its previous jurisprudence and adopt a more traditional interpretation of Islam. Furthermore, again in an attempt to constrain the interpretative authority of the Court, the Constitution

15 See in particular Case 20, Judicial Year 1 of May 4, 1985. In this ruling, the Court clarified that only laws adopted after the 1980 amendment of Article 2 of the Constitution had to be consistent with the principles of sharia. Following this amendment, principles of sharia ceased to be "a" source of legislation, and became "the main" source of legislation.

16 See Case 7, Judicial Year 8 of May 15, 1993. See also Case 8, Judicial Year 17 of May 18, 1996, available in English in Brown and Lombardi 1996: 437 et seq. 
introduced a new provision (art. 4), stipulating a requirement to consult Al-Azhar in matters relating to sharia (see Brown and Lombardi 2016: 255-258).

However, the 2012 Constitution did not produce the desired results, as it was suspended a few months later following the fall of President Morsi on July 3, 2013, and was subsequently replaced by the 2014 Constitution. Only two Islamists were represented in the new Constituent Assembly, with the consequence that liberals were able to (re-)establish the authority of the Supreme Constitutional Court to interpret sharia. Specifically, the framers maintained the wording of Article 2, but eliminated Article 219, did not confirm the consultative role of Al-Azhar, and included within the preamble a provision stating that, in defining the principles of sharia, "the point of reference for the interpretation thereof is the relevant texts in the collected rulings of the Supreme Constitutional Court" (see Brown \& Lombardi 2016: 258-259).

\section{Challenges and perspectives}

As has been pointed out by Clark Lombardi, in the MENA region there is currently "more constitutional review than ever before [...], and the institutions empowered to perform it have, at least on paper, new independence and power" (Lombardi 2014: 132). In fact, compared to the past, Arab constitutional courts and councils have significantly strengthened their position within the new constitutional frameworks, not to mention the fact that public opinion now seems to be more aware of the crucial significance of these institutions. From a practical standpoint, the role of constitutional review bodies in the transition processes following the Arab Spring has thus far varied enormously from country to country, making it extremely difficult to identify common trends. In general terms, however, in most cases constitutional courts and councils have displayed a high degree of deference to the political authorities. However, the case law of these bodies has not always been characterized by self-restraint: indeed, in some (albeit quite rare) situations constitutional courts have not hesitated to issue decisions that have clearly been unfavorable to the ruling regime, as was done by the Egyptian Supreme Constitutional Court 
during the Morsi regime. ${ }^{17}$ Furthermore, in some cases Arab constitutional justices have shown a greater commitment to the protection of rights and freedoms. In Jordan, for example, in 2013 the Constitutional Court recognized the right of public employees to form unions. In Egypt, in 2013 the Supreme Constitutional Court struck down Article 3 of Law 162/1958, which granted the President of the Republic the right to issue a verbal or written detention order or search warrant without being constrained by any criminal law procedures and guarantees. Moreover, in 2017 the Court granted Coptic civil servants the right to paid leave for one month in order to make a pilgrimage to Jerusalem, in the same way as Muslim civil servants have the right to paid leave of 30 days for the pilgrimage to Mecca (hajj). ${ }^{18}$

However, constitutional review bodies must still overcome numerous significant obstacles in order to contribute more effectively to the processes of democratization. In the first place, it must be pointed out that in several countries the legitimacy of these institutions is often questioned. Indeed, in many cases, due to the "counter-majoritarian difficulty", constitutional courts and councils are not readily accepted by other constitutional bodies and political actors. In Kuwait, for example, some Members of Parliament recently called for the abolition of the Constitutional Court, arguing - inter alia - that Parliament was the only institution that reflected the popular will (see Toumi 2019). In Lebanon, most of the political class is unwilling to strengthen the status and powers of the Constitutional Council, since "they don't want to be controlled by any institution" (Sleiman and Poll 2018: 3-4).

Another obstacle results from the fact that in many countries (as discussed above) the head of state continues to dominate the system for appointing the members of constitutional review bodies (such as in Syria, Jordan, Morocco and Egypt). Moreover, access to these institutions (although significantly expanded) is not always easy. As has been shown above, one need only consider the adoption of the "double-filter" system (rather than the "single-filter" system), or the decision to prevent the ordinary courts from referring questions of constitutionality ex officio. In Lebanon, the constitutionality of laws can only be challenged within

17 See in particular Cases 20 and 57, Judicial Year 34 of June 14, 2012, and Case 112, Judicial Year 34 of June 3, 2013. See Brown 2015: 33 et seq.; Brown and Waller 2016: 839 et seq.; Fadel 2018: 936 et seq.

18 For a comparative discussion of the role played by constitutional review bodies and the relevant case law in the transition processes following the Arab Spring see Biagi 2019: 656 et seq. 
fifteen days of their publication in the Official Gazette, not to mention the fact that only political and religious authorities are entitled to apply to the Constitutional Council, whereas the ordinary courts are not granted this power.

Poor legislative drafting is another element that must be taken into account. Indeed, ambiguities and gaps within the laws regulating the organization and functioning of constitutional courts hinder the functioning and actions of these bodies, thus weakening the system of constitutional review overall. In addition, in some cases these laws have not been updated, thus giving rise to legal uncertainties. In Jordan, for example, the Law on the Constitutional Court (No. 15 of 2012) still refers to the High Court of Justice (art. 11(3)(D)), which was replaced by the Administrative Court (court of first instance) and the High Administrative Court (court of second instance) (Law 27 of 2014). Since the Law on the Constitutional Court has not been updated, it is not clear whether the High Administrative Court can refer a question of constitutionality to the Constitutional Court directly, or whether it has to refer the question of constitutionality to the Court of Cassation (see Max Planck Foundation 2016-2017: 17).

Delays in implementing the new constitutional provisions on constitutional review represent another punctum dolens. In Morocco, for example, the Constitution was adopted in 2011, although the Constitutional Court was only established in 2017, and the Organic Law regulating the "exception of unconstitutionality" has not yet been promulgated (as discussed above). In Tunisia, where the Constitution entered into force in 2014, the Organic Law on the Constitutional Court was adopted in 2015, although a lack of agreement among the political forces has thus far prevented the majority required for the parliamentary appointment of one-third of the members of the Court from being achieved. ${ }^{19}$ Comparative experiences, however, show that postponing the establishment of constitutional review bodies and the enactment of the relevant laws risks weakening the "innovative force" which these institutions have when they are set up in a timely manner (see Biagi 2020: 192-193).

The context represents another obstacle that clearly does not help the action of constitutional courts and councils, since these bodies continue to operate in countries characterized by a weak separation of powers and poor constitutional culture. The only state that has thus far managed to make a clean break with its illiberal past is Tunisia, also thanks to the

19 On the consequences of the absence of the Constitutional Court in Tunisia see Democracy Reporting International 2019. 
adoption - on January 26, 2014 - of a profoundly democratic Constitution (see Ben Achour 2014: 783 et seq.; UNDP 2016; Ben Achour 2017; Groppi 2018: 343).

It is evident that, in the short term, the new Arab bodies for constitutional review have only rarely overcome the obstacles mentioned above. However, before jumping to definitive conclusions it must not be forgotten that these bodies are still young - in some cases they are even "newcomers" (as no similar institution previously existed for instance in Jordan or Palestine) - and need time to consolidate their position and prerogatives within the constitutional architecture. Therefore, a more accurate and reliable assessment of the performance of these new courts and councils will only be possible over the medium to long term.

\section{References}

Abouelenen, Mohamed Maher. 2008. "Judges and Acts of Sovereignty.” In: Judges and Political Reform in Egypt, edited by Nathalie Bernard-Maugiron. Cairo and New York: The American University in Cairo Press.

Aljidie, Fawaz. 2018. The Kuwaiti Constitutional System, Kuwait City.

Belaiz, Tayeb. 2013. "Allocution de M. Tayeb Belaiz, Président du Conseil Constitutionnel, à l'ouverture de la journée d'étude organisée à Alger, le 22 avril 2013, sur le thème 'L'extension de la saisine du Conseil Constitutionnel'." Revue du Conseil Constitutionnel 2.

Belguith, Brahim. 2015. "The Project of the Constitutional Court: Between the Obsession for the Organization and the Fear for the Instrumentalization" [in Arabic], Nawat, October 26, http://nawaat.org/

Benabdallah, Mohammed Amine. 2013. "Préface." In: Les grandes décisions de la jurisprudence du Conseil Constitutionnel [1994-2013]. REMALD 31, edited by Mohammed Benyahya.

Ben Achour, Rafâa. 2008. "Le contrôle consultatif de la constitutionnalité des lois par le Conseil constitutionnel tunisien.” In : Constitutions et pouvoirs. Mélanges en l'honneur de Jean Gicquel. Paris: Montchrestien - L'extenso éditions.

Ben Achour, Rafâa. 2014. "La Constitution tunisienne du 27 janvier 2014.” Revue française de droit constitutionnel 100: 783-801.

Ben Achour, Yadh. 2017. Tunisie. Une révolution en pays d'slam. Tunis: Cérès éditions.

Bendourou, Omar. 2004. "Le Conseil constitutionnel et les droits fondamentaux." Revue marocaine d'administration locale et de développement 56.

Bernard-Maugiron, Nathalie. 1999. "La Haute Cour constitutionnelle égyptienne, gardienne des libertés publiques.” Égypte/Monde arabe 2. 
Bernard-Maugiron, Nathalie. 2003. Le politique à l'épreuve du judiciaire: la justice constitutionnelle en Égypte. Bruxelles: Bruylant.

Biagi, Francesco. 2017. "The Algerian Constitutional Reform of 2016: A Critical Analysis." Global Jurist 17. 3.

Biagi, Francesco. 2018. "The Separation of Powers and Forms of Government in the MENA Region Following the 'Arab Spring': A Break with the Past?” Diritto pubblico comparato ed europeo 2.

Biagi, Francesco. 2019. "La giustizia costituzionale in Nord Africa e Medio Oriente in seguito alle primavere arabe." Quaderni costituzionali 3.

Biagi, Francesco. 2020. European Constitutional Courts and Transitions to Democracy. Cambridge: Cambridge University Press.

Biagi, Francesco. 2021. "Constitutional Review in Algeria Following the 2016 Reform: With Particular Reference to the 'Exception of Unconstitutionality", in this volume.

Boyle, Kevin and Adel Omar Sherif, eds. 1996. Human Rights and Democracy. The Role of the Supreme Constitutional Court of Egypt. London, The Hague and Boston: Kluwer Law International.

Brown, Nathan J. 1997. The Rule of Law in the Arab World: Courts in Egypt and the Gulf. Cambridge: Cambridge University Press.

Brown, Nathan J. 1998. "Judicial Review and the Arab World." Journal of Democracy 9.4 .

Brown, Nathan J. 2002. Constitutions in a Nonconstitutional World. Arab Basic Laws and the Prospects for Accountable Government. New York: SUNY Press.

Brown, Nathan J. 2015. "Egypt: A Constitutional Court in an Unconstitutional Setting." In: Political and Constitutional Transitions in North Africa. Actors and Factors, edited by Justin O. Frosini and Francesco Biagi. London: Routledge.

Brown, Nathan J. and Clark B. Lombardi. 1996. "The Supreme Constitutional Court of Egypt on Islamic Law, Veiling and Civil Rights: An Annotated Translation of Supreme Constitutional Court of Egypt Case No. 8 of Judicial Year 17 (May 18, 1996).” American University International Law Review 21.

Brown, Nathan J. and Clark B. Lombardi 2016. "Contesting Islamic Constitutionalism after the Arab Spring. Islam in Egypt's Post-Mubarak Constitutions.” In: Constitutionalism, Human Rights, and Islam after the Arab Spring, edited by Rainer Grote and Tilmann Röder. Oxford: Oxford University Press.

Brown, Nathan J. and Julian G. Waller 2016. "Constitutional Courts and Political Uncertainty: Constitutional Ruptures and the Rule of Judges." International Journal of Constitutional Law 14.4.

Cappelletti, Mauro. 1994. Dimensioni della giustizia nelle società contemporanee. Studi di diritto giudiziario comparator. Bologna: il Mulino.

Choudhry, Sujit, and Katherine Glenn Bass. 2014. Constitutional Courts after the Arab Spring: Appointment Mechanisms and Relative Judicial Independence. New York: IDEA and Center for Constitutional Transitions at NYU Law. 
Chentouf, Abdelhaif. 2019. "Exception d'inconstitutionnalité des lois: le gouvernement contraint de revoir sa copie.” Challenge.ma, June 24, https://www.challeng e.ma/exception-dinconstitutionnalite-des-lois-le-gouvernement-contraint-de-revo ir-sa-copie-111234/

"Constitutional Jurisprudence on Fundamental Rights: Digest of Selected Cases." 1996. In Human Rights and Democracy. The Role of the Supreme Constitutional Court of Egypt, edited by Kevin Boyle and Adel Omar Sherif. London, The Hague and Boston: Kluwer Law International.

Cotran, Eugene and Adel Omar Sherif, eds. 1997. The Role of the Judiciary in the Protection of Human Rights, London, The Hague and Boston: Kluwer Law International.

Democracy Reporting International. 2016. La Cour Constitutionnelle tunisienne. Analyse de la physionomie de l'institution après l'adoption de la Loi organique du 3 décembre 2015. Berlin and Tunis.

Democracy Reporting International. 2019. Les effets de l'absence de la Cour constitutionnelle pendant la législature 2014-2019. Berlin and Tunis.

de Montalivet, Pierre. 2018. "QPC et 'dialogue de juges'.” Revue française de droit constitutionnel 116.

de Visser, Maartje. 2015. Constitutional Review in Europe. A Comparative Analysis. Oxford and Portland: Hart Publishing.

Fabbrini, Federico. 2008. "Kelsen in Paris: France's Constitutional Reform and the Introduction of a Posteriori Constitutional Review of Legislation.” German Law Journal 9.10.

Fadel, Mohammad H. 2018. "The Sounds of Silence: The Supreme Constitutional Court of Egypt, Constitutional Crisis, and Constitutional Silence.” International Journal of Constitutional Law 16.3.

Fassi Fihri, Youssef. 2014. "Le Conseil constitutionnel marocain et le contrôle du législateur organique." In: La nouvelle Constitution marocaine à l'épreuve de la pratique, edited by Omar Bendourou, Rkia El Mossadeq and Mohammed Madani. Casablanca: Friedrich Ebert Stiftung.

Frosini, Justin O. and Francesco Biagi. 2015. "Transitions from Authoritarian Rule Following the Arab Uprisings: A Matter of Variables.” In: Political and Constitutional Transitions in North Africa. Actors and Factors, edited by Justin O. Frosini and Francesco Biagi. London: Routledge.

Gallala-Arndt, Imen. 2012. "Constitutional Jurisdiction and its Limits in the Maghreb.” In: Constitutionalism in Islamic Countries. Between Upheaval and Continuity, edited by Rainer Grote and Tilmann Röder. Oxford: Oxford University Press.

Garlicki, Lech. 2007. “Constitutional Courts versus Supreme Courts.” International Journal of Constitutional Law 5.1.

Ginsburg, Tom and Zachary Elkins. 2008. "Ancillary Powers of Constitutional Courts." Texas Law Review 87.

Groppi, Tania. 2018. "La Constitution tunisienne de 2014: illustration de la globalisation du droit constitutionnel?" Revue française de droit constitutionnel 114. 
Grote, Rainer. 2016. "Constitutional Review in Arab Countries. Down of a New Era?" In: Constitutionalism, Human Rights, and Islam after the Arab Spring, edited by Rainer Grote and Tilmann Röder. Oxford: Oxford University Press.

Kebaish, Karim Adel. 2019. "Tiran and Sanafir: A Historical and Constitutional Argument Opposing the Territorial Cession of the Tiran and Sanafir Islands to Saudi Arabia." Texas Law Review 97.

Lombardi, Clark B. 2008. "Egypt's Supreme Constitutional Court: Managing Constitutional Conflict in an Authoritarian, Aspirationally 'Islamic' State.” Journal of Comparative Law 3.2.

Lombardi, Clark B. 2014. "Constitutions of Arab Countries in Transition: Constitutional Review and Separation of Powers." In: Legal Studies Research Paper 2015-24. Barcelona: IE Med Mediterranean Yearbook, European Institute of the Mediterranean.

Maghraoui, Driss. 2013. "Constitutional Reforms in Morocco: Between Consensus and Subaltern Politics.” In: North Africa's Arab Spring, edited by George Joffé. London: Routledge.

Mallat, Chibli. 2007. Introduction to Middle Eastern Law. Oxford: Oxford University Press.

Max Planck Foundation for International Peace and the Rule of Law. 2016-2017. The Constitutional Court System in the Hashemite Kingdom of Jordan. High-Level Roundtable with the Constitutional Court and the Court of Cassation of Jordan (October 10-13, 2016). Heidelberg.

Mekki, Nidhal. 2018. "The Political Crisis in Tunisia: Is it a Consequence of the Semi-presidential Arrangement?" ConstitutionNet, December 7, http://constitutio nnet.org/news/political-crisis-tunisia-it-consequence-semi-presidential-arrangeme nt

Molfessis, Nicolas. 2011. "La résistance immédiate de la Cour de Cassation à la QPC.” Pouvoirs, 137.

Moustafa, Tamir. 2007. The Struggle for Constitutional Power: Law, Politics and Economic Development in Egypt. Cambridge: Cambridge University Press.

Moustafa, Tamir. 2008. "The Political Role of the Supreme Constitutional Court: Between Principles and Practice." In: Judges and Political Reform in Egypt, edited by Nathalie Bernard-Maugiron. Cairo and New York: The American University in Cairo Press.

National Human Rights Council. 2013. Memorandum on the Organic Law relating to the Exception of Unconstitutionality. Rabat.

Pouvoirs. 2011. No. 137 on the question prioritaire de constitutionnalité.

Sleiman, Issam and Robert Poll. 2018. "Towards a Reform in Lebanon? Interview with the President of the Constitutional Council Issam Sleiman.” VerfassungsBlog, June 20, https://verfassungsblog.de/towards-a-reform-in-lebanon-interview -with-the-president-ofthe-constitutional-council-issam-sleiman/

Stefanini, Marthe. 2013. "Le filtrage opéré par le Conseil d'Etat." Aix-Marseille Université, https:/www.researchgate.net/publication/281356900_Le_filtrage_op ere_par_le_Conseil_d'Etat 
Toumi, Habib. 2019. "Kuwaiti MPs Call for Abolishing Constitutional Court.” Gulf News, January 7, https://gulfnews.com/world/gulf/kuwait/kuwaiti-mps-call-f or-abolishing-constitutional-court-1.61290332

UNDP, ed. 2016. La Constitution de la Tunisie - Processus, principes et perspectives. Tunis, http://www.tn.undp.org/content/tunisia/fr/home/library/democratic_gov ernance/la-constitution-de-la-tunisie-.html

Venice Commission. 2011. Study on Individual Access to Constitutional Justice, January 27, http://www.venice.coe.int/WebForms/documents/default.aspx?pdffile= CDL-AD(2010)039rev-e

Venice Commission. 2013. Opinion on the Final Draft Constitution of the Republic of Tunisia, Opinion 733/2013, October 17, https://www.venice.coe.int/webforms/do cuments/?pdf=CDL-AD(2013)032-e

Venice Commission. 2015. Opinion on the Draft Institutional Law on the Constitutional Court of Tunisia, Opinion 817/2015, October 26, https://www.venice.coe.in t/webforms/documents/?pdf=CDL-AD (2015)024-e 
